\title{
STUDIES ON THE CRANIAL OSTEOLOGY OF THE BLIND CATFISH Horaglanis krishnai MENON (PISCES, CLARIIDAE)
}

\author{
T.V. Anna MERCY* and N. Krishna PILLAI
}

\section{SUMMARY}

Horaglanis krishnai Menon is a blind catfish inhabiting the dug- out wells at Kottayam, Kerala, South India. Studies on the cranial osteology of the fish show that the bones on the skull are firmly articulated. The frontoparietal fontanella is very large so that the cranium virtually lacks a roof. The sphenotics and alisphenoids are hardly recognizable and the orbital bones are entirely lacking. in osteological features $H$. krishnai closely resembles Uegitglanis zammaroni. But in H. krishnai the orbital bones are further reduced or even absent. The fontanella is larger than that of any other knawn catfish. These two species must have evolved from the same ancester and have taken up nearly identical ways of life. The difference between the skeletons of these two appears to be largely dependent on the relative size of the frontoparietal fontanella. Its greater development in H. krishnaj brought about a suppression or reduction of some of the bones clearly visible in Uegitglanis. It would appear that the modification initiated in Uegitglanis gatered momentum in Horaglanis. These two fishes form a group distinct from clariids and bagrids but form a connecting link between the two.

Keywords: horaglanis krishnai, cave fishes, osteology

\section{Introduction}

Cavefishes attracted the attention of ichthyologists only comparatively recently. Till date, 32 species of fishes have been recorded from caves, artesian wells and subterranean waters. The discovery of the new blind clariid fish from Keala, Horaglanis krishnai Menon (1950) and the occurrence of a similar blind clariid fish, Uegitglanis zammaroni Gianferrari 1932 from the former Italian Somaliland have raised points of great zoogeogarphical interest.

Our information about these two forms is, by no means adequate.

On a perusal of available literature it was found that extensive work has been done on the osteology of ostariophysean fishes. Publications deserving special mention are those of Regan (1911), Kindred (1919), Bhimachar (1933), Gregory (1933), David

*Associate Professor, College of Fisheries, Panangad, P.O. Cochin, Kerala, India This manuscript form part of $\mathrm{Ph} . \mathrm{D}$ thesis of the first author. 
(1935), Merriman (1940), Nawar (1954), Joseph (1960) Srinivasachar (1956/57), Dutta et al (1975) and Fink and Fink (1981).

It has been found that there is little work on blind fishes. The only important paper on this subject is by David (1935) on the osteology of Uegitglanis zammaroni In the present study, a detailed account of the cranial osteology of Horaglanis krishnai is furnished and compared with that of Uegitglanis zammaroni in detail.

\section{Materials and methods}

Horaglanis krishnai occurs at the bottom of the dugout wells at Kottayam, (Lat. $8^{\circ} 4^{\prime} \mathrm{N}$ and $10^{\circ} 21^{\prime} \mathrm{N}$; Lougitude $76^{\circ} 13^{\prime} \mathrm{E}$ and $77^{\circ} 8^{\prime} \mathrm{E}$ ) Kerala, South India. Specimens of $H$. krishnai were collected from the dugout wells at Kottayam. As the fishes invariably rest on the bottom they could be collected only by draining the wells. Osteological descriptions are based on Alizarin preparations of head of 20 individuals ranging in length from $2.0-2.9 \mathrm{~cm}$. The positions of the various bones were carefully noted from Alizarin preparations. For detailed study of the shape and size of individual bones, the bones were disarticulated from the cranium under binocular microscope. Sketches were made with the aid of camera lucida.

\section{Results}

The skull is twice as long as broad and steadily narrows forwards (Fig. 1\&2). It is widest at the auditory region. As the bones are connected by sutures and even partially fused, the boundaries of individual bones can be made out only with difficulty. The skull has a large dorsomedian fontanella and hence the cranium lacks a roof. The fontanella is anteriorly bordered by the dermethmoid, posteriorly by the supraoccipital and laterally by the frontoparietals.

\section{Dermethmoid: (Figs.3 \& 4)}

The dermethmoid is a median dorsal bone situated at the anterior end of the skull. It has two small frontal processes articulating with the premaxilla in front. Posteriorly, it is drawn out into two stout processes, which articulates with the anterior ends of the frontoparietals. The posterior ventral part of the dermethmoid is excavated and into this excavation fits the anterior extremity of the parasphenoid. The dermethmoid contacts the premaxilla anteriorly; the frontoparietals posteriorly; the parasphenoid 


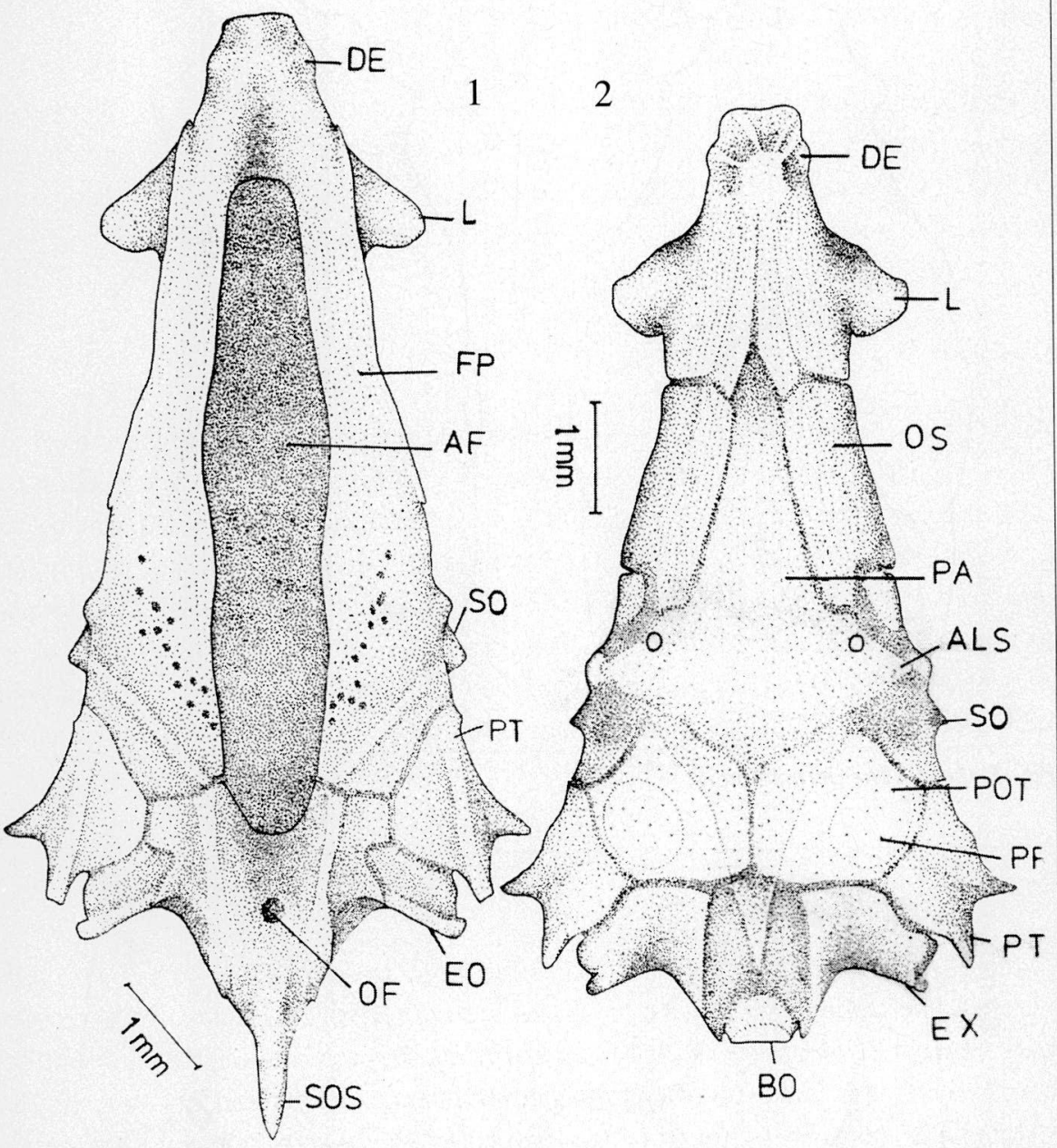

Fig. 1 and 2 - The skull.

ventrally and the lateral ethmoids laterally. The posterior concavity forms the anterior boundary of the fontenella.

\section{Lateral ethmoids: (Fig.5 \& 6)}

The lateral ethmoids are paired bones on either side of the dermethmoid. They are irregular in shape with a posterolateral triangular process, which extends over half 

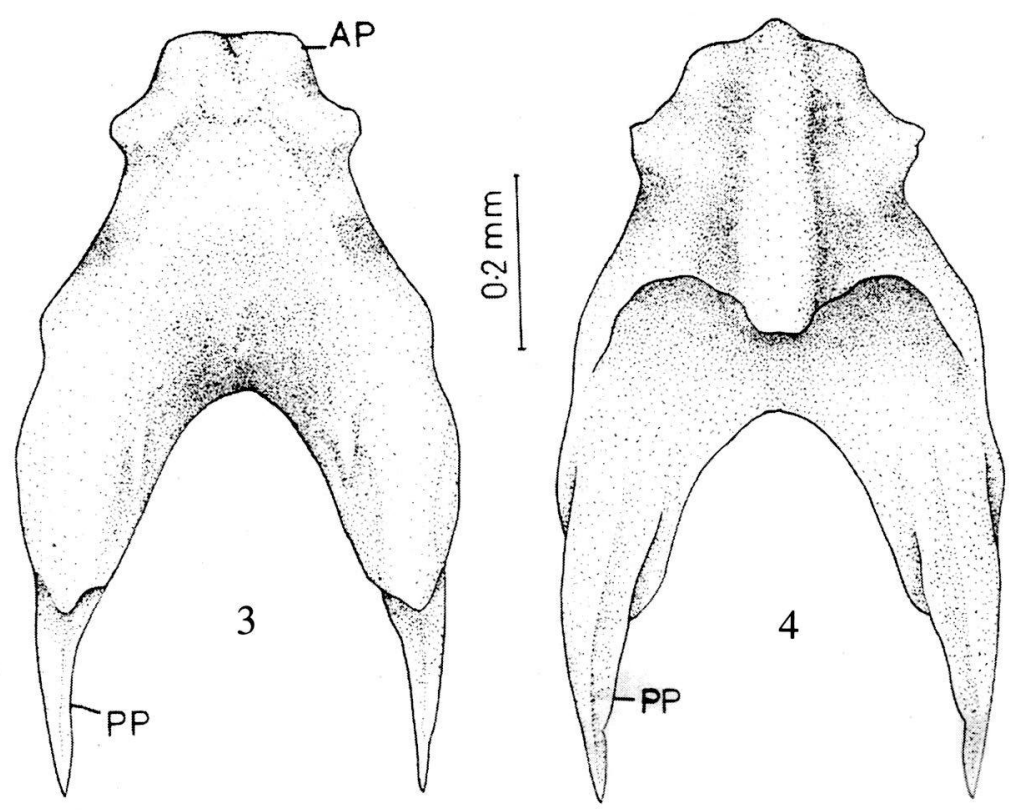

Fig. 3 and 4 - The dermethmoid.
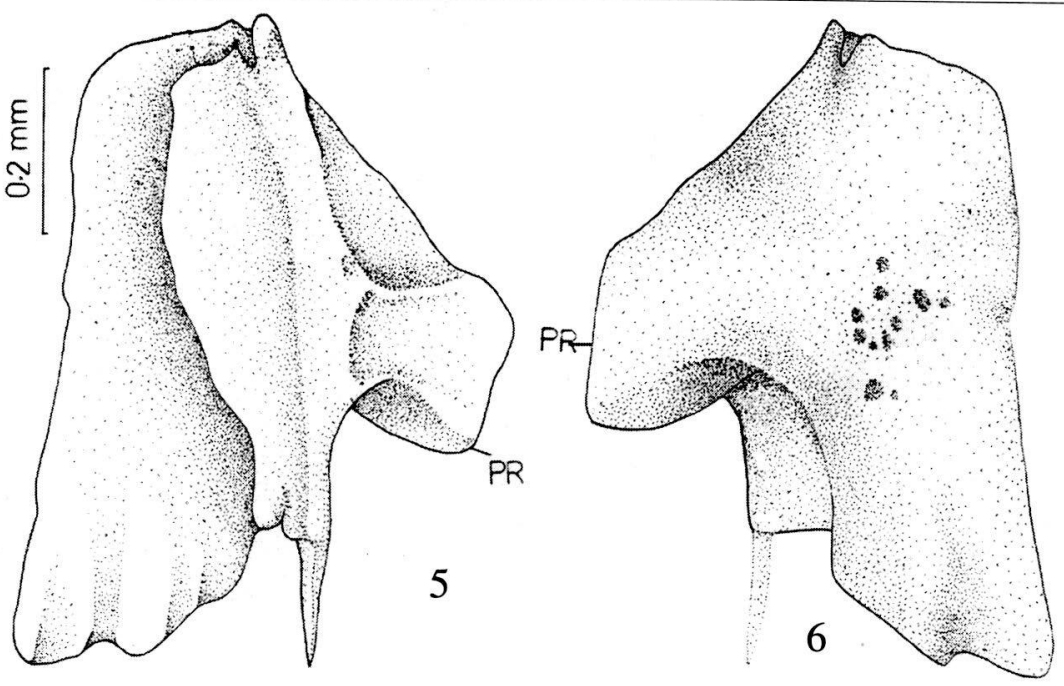

Fig. 5 and 6 - The lateral ethmoids. 
the length of the premaxilla. The lateral ethmoids do not meet along the midventral line but leave a narrow space between. Into this narrow space fits the anterior end of the parasphenoid. The lateral ethmoids articulate with the orbitosphenoid posterior, dermethmoid and front parietals dorsally, premaxilla interiorly and parasphenoid ventrally.

Frontoparietals: (fig.7)

The bones, which laterally border the large median fontanella, are referred to as the frontoparietals. David (1936) used the same name in describing the skull of $U . z a m-$ maroni. The frontoparietals are elongated bones contributing three fourths of the boundary of the fontanella. They are fused with the sphenotics producing a pair of complex irregular bones. The posterior ends of these bones are pointed and overlap the anterior end of the supraoccipital.

\section{Supraoccipital: (Figs. $8 \&$ 9)}

This is a dors median, well-demarcated bone. Anteriorly it is broad, with two lateral wing-like expan-

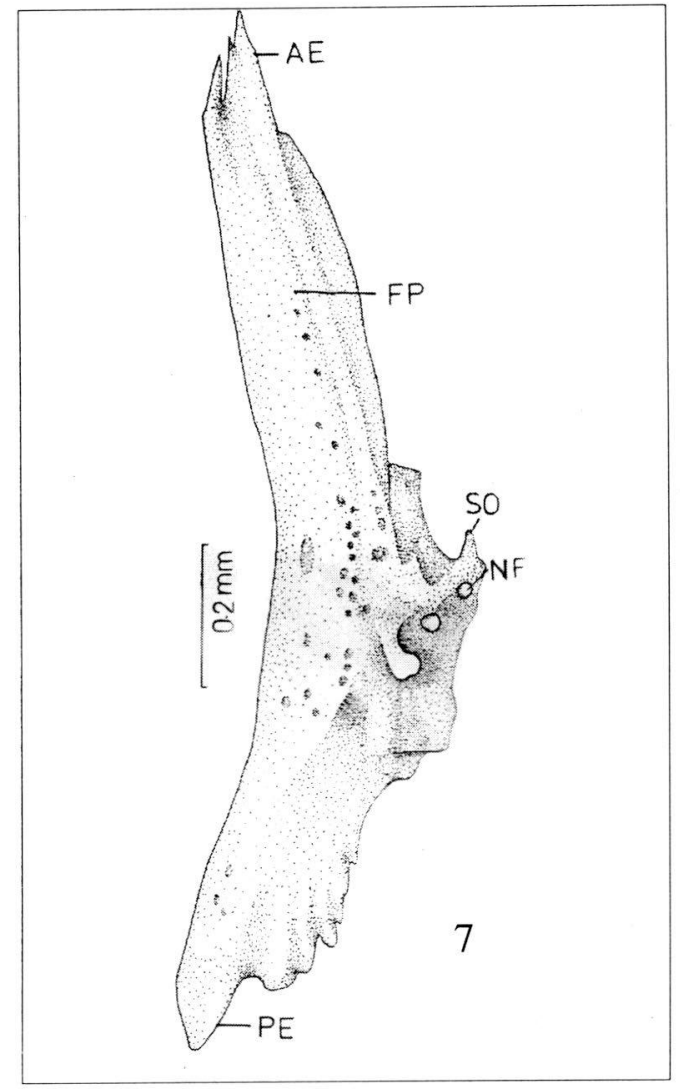

Fig. 7 - The frontoparietal. sions, but narrows backwards.

There is a well-defined sharp supraoccipital spine. A small oval occipital fontanella is observed at the middle of this bone. The anterior concavity of the supraoccipital spine articulates with the neural spine of the complex vertebra. The supraoccipital spine is very prominent and occupies hal fthe total length of the bone. The hind part of the front parietals abuts on the lateral grooves on the dorsal side of the occipital bone. The supraparietal bone, which is the largest of the occipitals joins the frontoparietals anteriorly and the pterotics and epiotics laterally. 


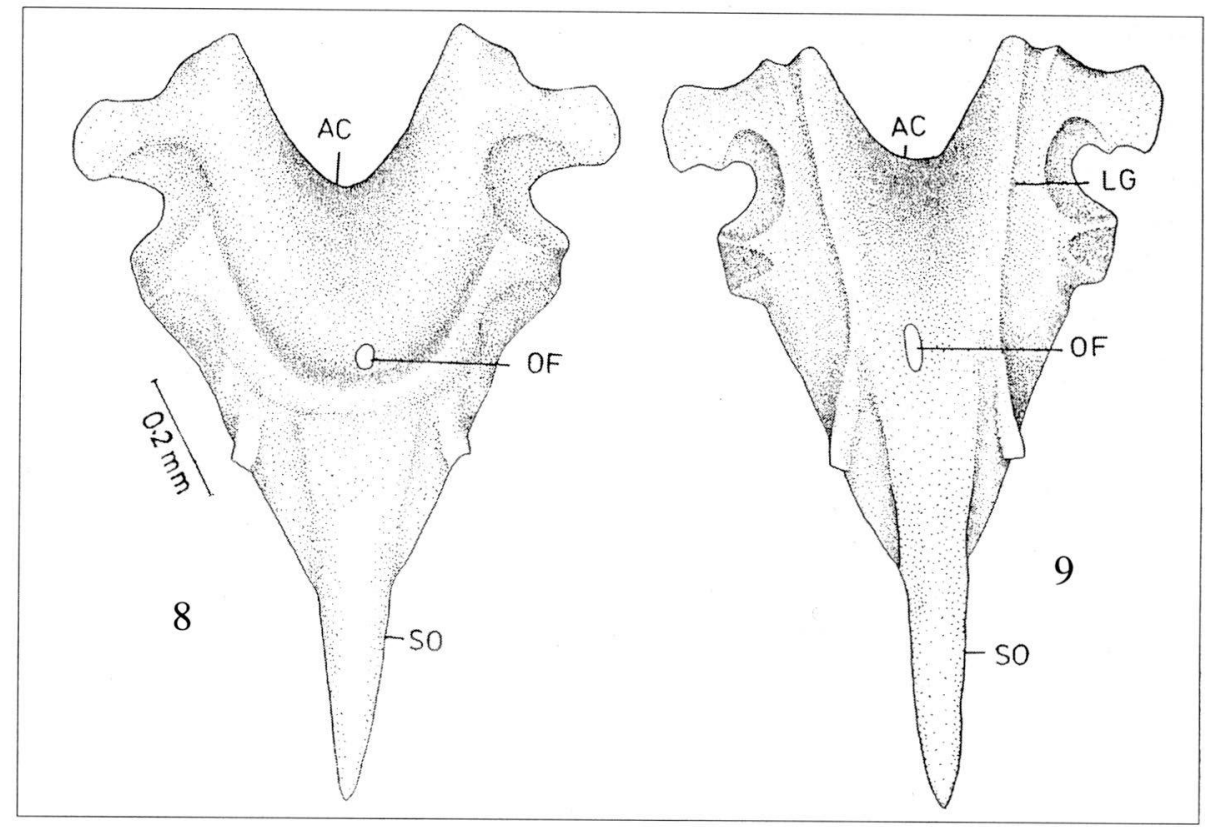

Fig. $8 \& 9$ - The supraoccipital.

\section{Exoccipital: (Fig.10)}

The exoccipitals are large, irregular bones situated ventrolaterally, on either side of the foramen magnum. There is a concavity on their anterior side. These bones form the posterior boundary of the otic capsule. Each exoccipital is connected suturally with the basioccipital ventrolaterally, prootics anteriorly and the epiotics posteriorly.

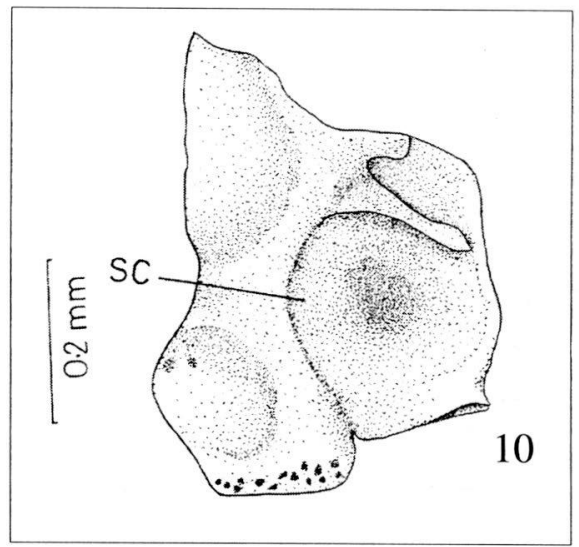

Fig. 10 - The exoccipital.

\section{Basioccipital: (Fig. 11)}

This is a single, ventromedian bone forming the posterior end of the neurocranium. Its anterior part is roughly triangular and the posterior cylindrical. At its hind end the basioccipital carries the occipital condyles, whose posterior surface is deeply con- 
cave and similar to that of the centrum of the vertebra, and provides an articulating surface for the complex vertebra The anterior end is very thin and is prolonged into a forked process, which is suturally connected to the posterior end of the Parasphenoid. The basioccipital is bounded laterally by the exoccipitals, anteriorly by the prootics and parasphenoid and dorsslly by the epiotics. This bone forms the ventral boundary of the foramen magnum.

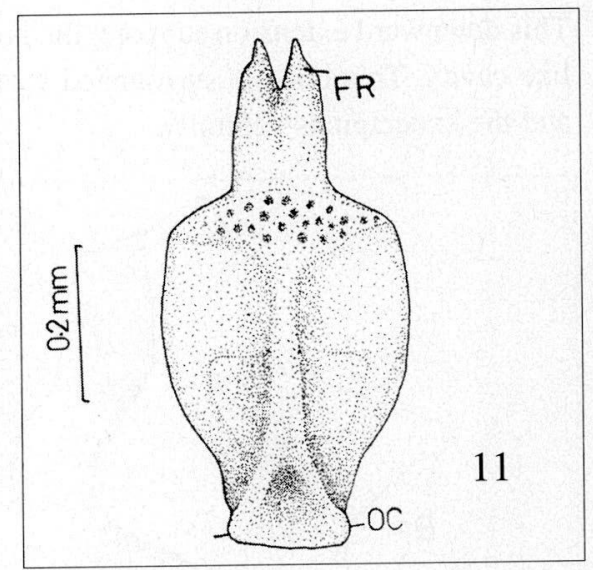

Fig. 11 - The supraoccipital.

\section{Spheuodes:}

The sphenotics are fused to the middle region of the front parietals laterally and are not demarcated as distinct bones of the roof of the cranium. Each sphenotic has two sharp ridges, giving articulation to the hyomandibular. The sphenotics extend ventrolaterally to form the posterior boundary of the optic foramen The ventrolateral extension of the sphenotics contacts pterotics behind and the prootics and parasphenoid ventrolaterally. The lateral extension of this bone has two small foramina through which pass the trigeminal and facial nerves. The lateral ridges of the front parietals and the sphenotics are comparatively thick.

\section{Pterotics (Fig. 12)}

Pterotics are highly arched, paired bones forming the posterolateral parts of the cranial roof. These irregular bones take part in the formation of the auditory capsules. The dorsolateral edge of the pterotic bone has a bifid lateral pterotic process, which articulates with the post temporal and hyomandibular. The pterotics contact the prootics ventrolaterally, and the epiotics and exoccipitals posteriorly. Dorsally, the pterotics are connected to the supraoccipital.

Epiotics: (Fig. 13)

These paired bones form the posteriormost part of the auditory capsule and are situated on either side of the supraoccipital. Each epiotic has small spinous process, which arises from the posterior end of the outer surface and proceeds downwards. 
This downward extension supports the post temporal. The epiotic has a shallow, bowl like cavity. This bone is surrounded by the supraoccipital and the pterotic dorsally and the exoccipitals ventrally.

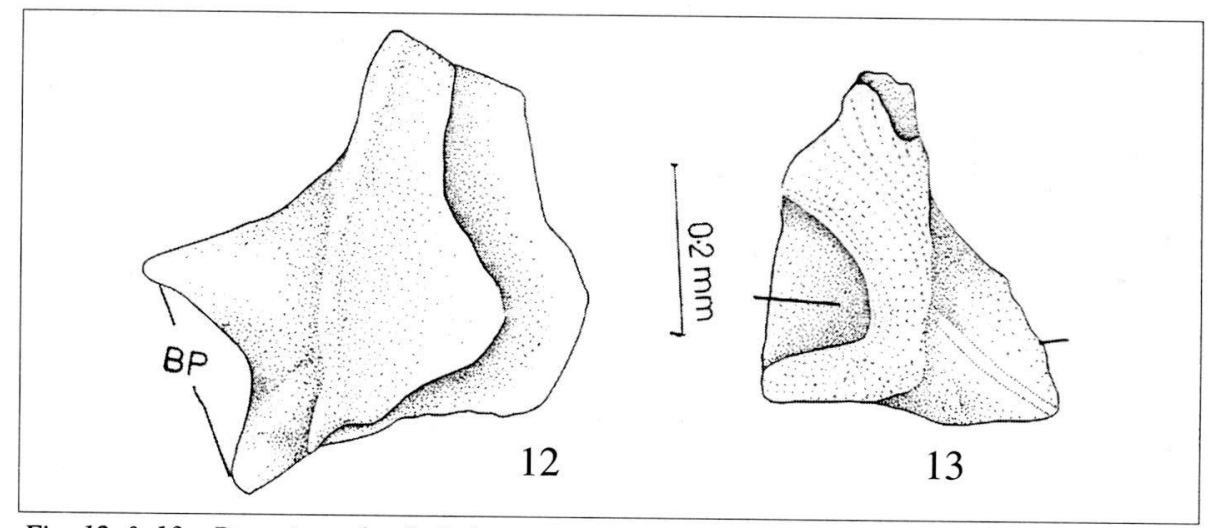

Fig. 12 \& 13 - Pterotic and epiotic bones.

Prootics: (Fig. 14)

The prootics are large, flattened bones which lie on the posterior ventral region of the neurocranium. They have nearly semicircular concavity to lodge the otolith. The two

prootics meet along the midventral line over the parasphenoid thus completing the

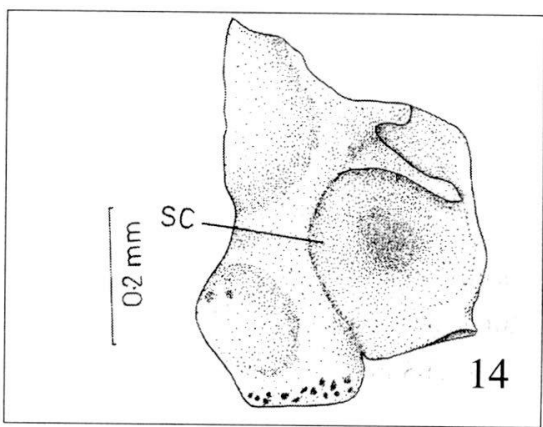

Fig. 14 - Prootics

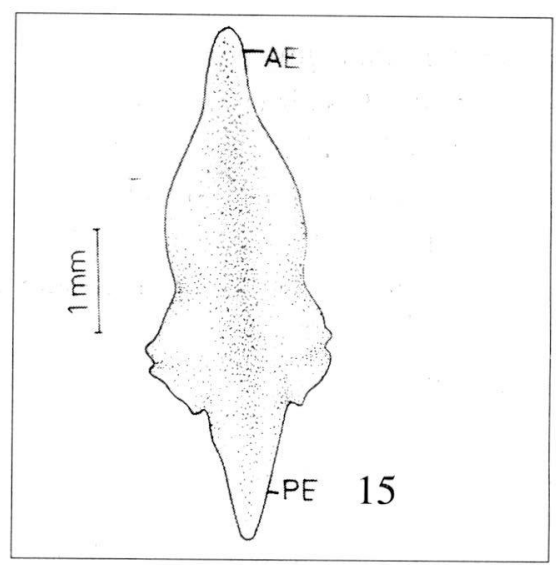

Fig. 15 - Parasphenoid
The parasphenoid is a median, ventral
dagger shaped bone supporting the floor

The parasphenoid is a median, ventral
dagger shaped bone supporting the floor

floor of the cranium there. From the dorsal side of the prootics proceeds forwards a splint of bone, which contacts a small process of the pterotic. Anteriorly, the prootics are connected with the parasphenoid, laterally with the pterotics and sphenotics and posteriorly with the exoccipitals and the basioccipitals.

\section{Parasphenoid: (Fig.15)}


of the whole cranium. It is comparatively very thin. Its anterior constricted part is inserted into the hollow ventral part of the dermethmoid. The parasphenoid extends from the basioccipital to the dermethmoid and is concave midventrally. It is broad in the middle and narrow at both ends. Anteriorly it is connected to the dermethmoid and lateral ethmoids, posteriorly to the basioccipital and prootics and anterolaterally to the orbitosphenoid. The alisphenoid is so intimately fused with the parasphenoid that it cannot be easily separated. The alisphenoid form the ventrolateral boundary of the optic foramen.

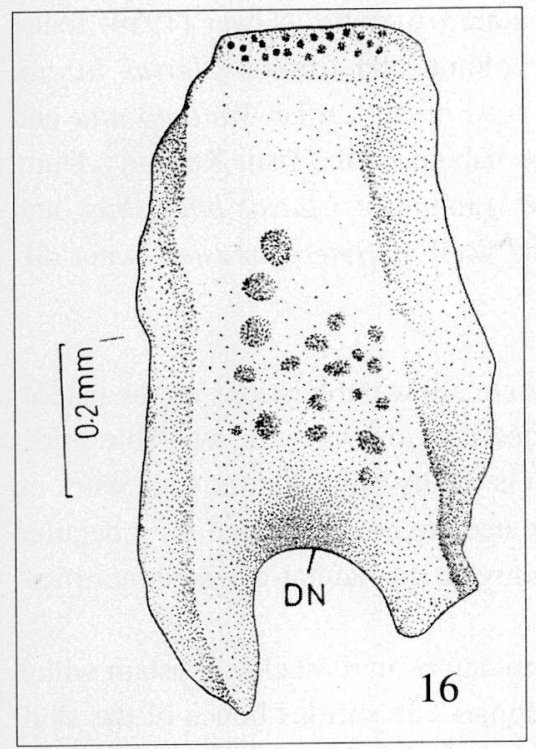

\section{Orbitosphenoid: (Fig. 16)}

The orbitosphenoids are a pair of well-developed bones forming the ventrolateral parts of the skull and taking parting the formation of the sidewalls of the cranial cavity. The deep notch on its hind end forms nearly half the anterior boundary of the optic foramen. The anterior portion of the sphenotics and alisphenoid forms the rest of the boundary. Each orbitosphenoid joins the frontoparietals above, the parasphenoid below and the lateral ethmoids in front. In $H$. krishnai the orbital bones are apparently absent.

Fig. 16 - The orbitosphenoid.

\section{Discussion}

There is indeed an abundance of literature on the osteology of fishes. But catfishes do not appear to have attracted sufficient attention. Regan (1911) classified the Ostariophysii on the basis of their cranial osteology. Bhimachar (1933) studied the osteology of eight catfishes namely, Rita buchanani, Silundia gigantica, Plotosus canius, Wallago attu, Pangassius buchanani, Macrones aor, Arius sona, Arius sagore and Osteogeneosus mulitaris. This comparative study helped the author to fix the taxonomic position of each of the species. Gregory (1933) studied the osteology of Clariidae and Bagridae and discussed the evolution of Ostariophysii. David (1935) studied clariid genera, Clarias, Allabenchyles, Clariallabes, Channallabes, Heterobranchus, Dinopterus and Uegitglanis. In this exhaustive treatise, the author 
has given brief description of the skulls of all the species taken up for investigation. This work, more than any other, helped in undersanding the philogeny of Clariidae. David (1936) described the skull of Uegitglanis zammaroni, the blind siluroid discovered in the former Italian Somaliland. In this work he gave a discussion of the special features of the head skeleton of Clariidae and Bagridae. He mentioned the peculiarities of the skull of Uegitglanis and came to the conclusion that it is intermediate between that of Clariidae and Bagridae.

Merriman (1940) dealt with the osteology of Galeichthys felis and Bagre marinus, two large forms of catfishes inhabiting the southern Atlantic. Nawar (1954) made detailed observations on the skull, vertebral column and fins of Clarias lazera. Joseph (1960) described the osteology of the head of the catfish Wallago attu and correlated the modifications observed with the habitat of the fish. Recently Dutta et.al., (1975) made a comparative study of the cranium of Clarias batrachus and Heteropneustus fossills. Their description of the skull of Heteropneustus is not different from that given by Bhimacbar (1933).

From the above it can be seen that though there are a few publications on the osteology of catfishes, including one on a blind species (David 1936), the available information is by no means adequate. As H. krishnai is totally blind and the only work on a similar fish is that of David (1936), this alone need to be considered for a detailed comparison. The account will, therefore, be mainly on the habitat-oriented modifications in the osteology of $H$. krishnai.

H. krishnai shows a number of significant modifications in its skeletal system which can be directly correlated with its habit and habitat. The various bones of the skull are firmly articulated by sutures. This might be helpful in a fish, which moves about through narrow subteanean channels where the chances for the head striking against hard objects are high. However, a cephalic shield, composed of the supraorbitals, dermosphenotics and the post temporals, which is found well developed in other catfishes (Joseph, 1960) is absent in H. krishnai. But the cranial roof is similar to that of other clariids, and of Clariallabes and Channallabes in particular, which are partially blind, and Uegitglanis zammaroni, which is totally blind. The roof of the cranium of $H$. krishnai is reduced to the narrow frontoparietals enclosing between them large, elongate, elliptical fontanella. The frontoparietals and the sphenotics are fused together to form a complex irregular bone. In Uegitglanis (David, 1930) the frontoparietals are broad, which, along with the supraoccipital, form the dorsal surface of the cranium. The fusion of the frontoparietals with the sphenotics into a complex structure may be presumed to be a step towards increasing the rigidity of the skull. 
In typical catfishes the dovetailing of the bones of the dorsal shield provides necessary strength to the roof of the cranium.

Among the catfishes, in general, the anterior halves of the frontals remain separated by wide fontanella. There is also another foramen of the supraccipital bone. The size and extent of these fontanellae vary in different species. In Bagrus (David, 1936) both fontanellae are linear and separated by a thin median parietal bone. In Bagrus the two fontanellae are similar but in all others the supraoccipital fontanella is small. In $H$. krishnai the anterior fontenella is exceptionally broad, exposing most of the dorsal surlace of the brain. This is a unique feature of the skull of $H$. krishnai. The development of such a large fontanella must be considered as a result of the degeneration and disappearance of the eyes. A transparent thin smooth membrane covers the fontanella. The obvious inference is that the mid brain did not provide any evidence for this surmise, though this is the only way the presence of an elongated fontanella can be explained.

The pterotics in H. krishnai are strong, laterally arched bones of the cranial roof, taking part in the formation of auditory capsule. In both Uegitglanis and Bagrus the pterotics are laterally situated and associated with the auditory capsule. The same condition is noticed in $H$. krishnai also.

In H. krishnai the sphenotics can be hardly be recognized. In Uegitglanis the sphenotics form a marginal border of the cranial roof. In Clariallabes and Channallabes the sphenotics are pushed outwards by a broad process of the frontoparietals. They take practically no part in the formation of the cranial roof. It would appear that the habitat and partial or total blindness of fishes have influenced the size and position of the sphenotics.

The orbitosphenoids are well-developed bones forming the lateral wall of the anterior part of the cranium. Bhimachar (1933) observed that the presence of a welldeveloped orbitosphenoid is an archaic feature. But its persistence, even in highly specialized species, is probably because it helps in the attachment of the ethmoid region to the rest of the cranium (Bhimachar 1933).

In most teleosts the basisphenoid is a small median' $Y$ ' shaped bone placed above the parasphenoid. Whether this bone is present or not in Ostariophysii is still being debated. Kindred (1919) and de Beer (1937) observed it in Ameiurus but Sagemehl (1891) and Berg (1940) did not. Bhimachar (1933) found the bone in all catfishes he studied and according to him in Wallago attu it can be seen on the ventral aspect of the parasphenoid. However, Joseph (1960), who studied Wallago attu in detail, 
observed that this bone is not visible and that there is no indication that it is fused with the parasphenoid. In $H$. krishnai the basisphenoid is certainly absent. It seems that the uncertainty regarding the presence or absence of the basisphenoid indicates that among catfishes this bone has been undergoing reduction ending in its disappearence as in H. krishnai.

The degree of development of the supraoccipital spine is often taken as an index of evolutionary advancement. This assumption is based on the finding that in the precretaceous bony fishes the base of the cranium was nearly flat and the supraoccipital process was absent. (Woodward 1898). In H. krishnai the supraoccipital process is well developed. The same condition is observed in Uegitglanis also. In the admittedly more primitive Silundia and Wallago (Bhimachar 1933) the supraoccipital is small. Thus this bone, unlike the basisphenoid is undergoing progressive development.

The dermethmoid in H. krishnai is a median bone with two short anterior processes articulating with the premaxilla. It is firmly fused with the front parietals posterior. In Uegitglanis the bone is even, except for a short deut in the middle, forming the anteriormost part of the boundary of the fontanella. The clariids and bagrids differ particularly with regard to the bones, which form the sides of their cranium. In the degenerated clariids, Clariallabes and Channallabes, those bones are reduced but clearly recognizable (Regan 1911; David 1935). In these forms the dermosphenotics are rudimentary structures. In Uegitglanis it is exactly as in Channallabes. But in bagrids it is still more modified forming a unique bone associated with the preopercle. But the orbital bones of Uegitglanis correspond with those of bagrids. In latter they are modified into tubular structures, surrounding the mucus canals, which originates from the sphenotics and terminates in the maxillary after taking a curve around the eye. In Channallabes the orbital bones are reduced to a cartilaginous ring around the eye. In H. krishnai those bones are absent. This obviously is due to the total absence of the eyes.

The eye muscle canal or the myodome is supposed to be absent in siluroids. It is absent in all the catfishes studied by Bhimachar (1933). But in the primitive Silundia Bhimachar (1933) found a small vestige of the myodome, persisting between the prootics, the parasphenoid and basioccipital. This indicates that the myodome must have been well developed and functional in the ancestral silurids. A rudiment of the myodome was noticed in Ameiurus by Murrich (1884). In H. krishnai the myodome is absent. It can, therefore, be concluded that $H$. krishnai belongs to the more 
advanced group of catfishes in which the myodome has been obliterated by the secondary simplification of this region of the skull. The secondary simplification must have got accelerated due to the degeneration of the eyes.

The cavum cranii of $H$. krishnai extends up to the ethmoid region. Hence, the cranium is platybasic. The platibasic nature of the cranium of siluroids is considered to be primitive nature (Bhimachar, 1933). In Uegitglanis the cavum cranii is normally developed but highly reduced in the middle. The same is true of Channallabes. Joseph (1960) came to the conclusion that the cranium of Wallago attu is of a primitive type. Bhimachar (1933) found that, of the eight species of catfishes he studied, six have a primitive type of skull. He suggested that the skull of Arius and Osteogeneosus are more evolved.

In osteological features H.krishnai closely resembles Uegitglanis. But in H. krishnai the orbital bones are further reduced or even absent. The fontanella is larger than that of any other known catfish. These two species must have evolved from the same ancestor and have taken up nearly identical ways of life. The difference between the skeleton of these two appears to be largely dependent on the relative size of the frontoparietal fontanels. Its greater development in $H$. krishnai brought about a suppression or reduction of some of the bones clearly visible in Uegitglanis. It would appear that the modifications initiated in Uegitglanis gathered momentum in Horaglanis. These two fishes form a group distinct from clariids and bagrids but form a connecting link between the two.

\section{References}

BERG L. S. 1940 Classification of fishes, both recent and fossil. Trav. lnst. Zool. Acad. Sci., U.S.S.R. Leningrad, 5: 87-517

BHIMACHAR B. S. 1933 On the morphology of the skull of certain Indian catfishes. Halfyrly. J.Mysore Univ., 7:233-265.

DAVID L. 1935 Die Entwicklung der Clariiden und ihre Verbreitung. Eine anatomischSystematische Untersuchung. Rev. Zool.Bot.Afr. 28:77-146

DAVID L. 1936 Uegitglanis, Silure aveugle de la Somalie itatienne chainon entre Bagrids et Clariides. Rev.Zool. Bot.Afr. 28:370-387.

DE BEER G.R. 1937. The development of vertebrate skull, Claredon Press, Oxford.

DUTTA N. C., A. K. SAILA \& A. BAIDYA. 1975 Comparative study of Osteocranium and Weberian apparatus of Cianus batrachus (Linn.) and Heteropneustes fossills (B1.). Zool. Anz, 195:374-386 
FINK S. V. \& FINK W. L. 1981 Interrelationship of the ostariophysan fishes (Teleostei). Zool. J. Linn. Soc., 72 (4): 297-353.

MC MURRICH 1884 The osteology of Amiurus catus.Proc. Canad. Inst., 2:270

GREGORY W.K. 1933 Fish skuls-A study of the evolution of natural mechanism. Trans. Am. Phil. Soc., 23: 1- 481.

JOSEPH N. I. 1960. Osteology of Wallago attu (Bloch \& Schneider). Part I. Osteology of the head. Proc. Natn. Inst. Sci. India, 26:205-236.

KINDRED J. E. 1919 Development of skull in Ameiurus. Illinois boil. Monogr., 5.

MERRIMAN D. 1940 Morphological and embryological studies on two species of marine catfish, Bagre marinus and Galeichthys felis. Zoologica, N.Y., 25: 221-228.

NAWAR G., 1954. On the anatomy of Clarias lazera. I Osteology. J. Morph, 94: 557-586.

REGAN T. C. 1911. The classification of the teleostean fishes-2 Siluroidea Ann. Mag. Nat Hist.,47:

SAGEMEHL M. 1891 Beitrage zur vergleichenden Anatomie der Fische. IV Das Crenium der Cyprioiden. Morp. Jb., 17:489-595

SRINIVASACHAR A. R. 1956 Development of the skull in catfishes. Part I Development of chondrocranium in Silonia, Pangassius and Ailla (Schilbeidae) Proc. Natn. Inst. Sci. India, 22: 335-356.

SRINIVASACHAR A. R. 1957 Development of skull in catfishes. Part II Developinent of chondrocranium in Mitus and Rita (Bagridae). Morph.Jb., 98:244-262.

WOODWARD, A. S. 1898 Vertebrate Paleontology, Cambridge.

\section{Acknowledgements}

The first author is grateful to CSIR, New Delhi for the award of a fellowship during the tenure of which the work was carried out. She is also thankful to Mr. K.G. Padmanabhan, Reader, Department of Aquatic Biology \& Fisheries, Trivandrum for his help in the preparation of the manuscript. 